\title{
Effect of inulin on dough and biscuit quality produced from different flours
}

\author{
Maria S. Blanco Canalis ${ }^{a}$, Alberto E. León ${ }^{a}$ b, and Pablo D. Ribotta a, c, d* \\ ${ }^{a}$ Instituto de Ciencia y Tecnología de los Alimentos Córdoba (ICYTAC), CONICET - Universidad Nacional de \\ Córdoba (UNC), Córdoba, Argentina \\ b Facultad de Ciencias Agropecuarias, UNC, Argentina \\ ${ }^{\mathrm{c}}$ Facultad de Ciencias Exactas, Físicas y Naturales, UNC, Argentina \\ d* Instituto Superior de Investigación, Desarrollo y Servicios en Alimentos (ISIDSA), UNC, Córdoba, Argentina \\ ${ }^{*}$ Corresponding author \\ pdribotta@unc.edu.ar \\ TEL: +543514629520
}

Received: 11 May 2016; Published online: 18 April 2017

\begin{abstract}
One of the methods of improving the nutritional profile of baked-goods is the incorporation of dietary fibre (DF) to the formulation. However, DF retains more water than wheat flour which, affects dough rheological properties and thus the final product quality. Flour is the main ingredient in biscuits and contributes to the baked texture and shape of biscuits. There are large differences in quality among the flours from wheat cultivars and among non-wheat flours used for biscuit production. In previous works, different dietary fibres were tested and inulin was found to have a positive quality effect on biscuits made from an all-purpose wheat flour without the need of introducing significant changes in dough properties. To know whether these results are extended to different types of flours that can be used for biscuit production, this paper aimed to analyse the effects of different levels of inulin incorporation on dough and biscuits quality made from three different wheat flours and one triticale flour. Chemical and physic-chemical characterization of the flour samples was performed and compared (moisture, ashes, gluten, solvent retention capacity (SRC) and protein content). Inulin was incorporated to biscuits formulation in two levels: 6 and $12 \%$ (wheat replacement). Dough and biscuits quality was measured by spread rate during baking and biscuit factor, texture and surface colour. Inulin incorporation increased dough spreading and biscuit factor and decreased biscuit hardness. The enhancing effect of inulin was observed in all flour. The results confirmed the effect of inulin on biscuits obtained with all flour assayed, despite the differences in flour quality that was tested.
\end{abstract}

Keywords: Flour quality; Inulin; Dough spreading; Biscuit factor; Biscuit texture; biscuit colour

\section{Introduction}

Biscuits, known as short dough, are one of the most popular and consumed product worldwide. Particularly, in the past 10 years, domestic consumption of biscuits and crackers in Argentina increased considerably, and reached a per capita consumption of approximately $13 \mathrm{~kg}$ per year, one of the highest consumption rates in the world
(Samela, 2011).

Short-dough biscuits are usually made from wheat flour and a large amount of sugar and fat. These ingredients are responsible of the distinctive characteristics of this kind of product. Flour is the main ingredient in most biscuits, which mainly contributes to the texture and shape of biscuits. There are significant differences in quality among flours from wheat cultivars and among 
non-wheat flours which can be used for biscuit production. 'Weaker' wheat flours are traditionally deemed most suitable for biscuit making. The main properties of wheat flours of interest to biscuit production are the quantity and quality of protein, the particle size distribution, the damaged starch content and their effect on the water absorption property.

Soft wheat flours with low protein content and water absorption and small size produce good quality biscuits characterized by a good degree of expansion during baking and a large biscuit diameter, reduced thickness, and tender texture (Morris \& Rose, 1996; Abboud, Rubenthaler, \& Hoseney, 1985; Pareyt \& Delcour, 2008).

Biscuits made from hard wheat flour present a controlled elastic spreading that results in a limited spread during baking until it reaches a maximum followed by a degree of shrinking (Slade \& Levine, 1994). However biscuits made from soft wheat flour spread to a maximum diameter and then collapse drastically, resulting in thin great quality products.

Soft wheat crops in Argentina are not extensively developed, so the biscuit industry uses bread flours and specific additives to minimize the formation of gluten and water absorption during the manufacturing processes (Moiraghi, Ribotta, Aguirre, Pérez, \& León, 2005).

Triticale ( $\mathrm{x}$ Triticosecale Wittmack) is a hybrid resulting from the crosses between wheat (Triticum sp.) and rye (Secale sp.). This crop is considered an alternative for human consumption, as it is more resistant to adverse conditions than the wheat crop (Bushuk \& Larter, 1980; CIMMYT, 1985; Varughese, 1991). Previous studies had shown that Triticale flours with low amount of proteins and glutelins and large amount of prolamins are a good alternative for biscuit production (Leon, Rubiolo, \& Anon, 1996; Aguirre et al., 2002; Rubiolo, Ferretti, Ribotta, Aguirre, \& León, 1998; Tsen \& Tsen, 1974).

One of the strategies used to improve the nutritional profile of these highly consumed worldwide products is the incorporation of dietary fibre (DF) to its formulation. DF is a vegetal portion that is not hydrolysed by digestive enzymes of human upper gastrointestinal tract and undergoes to partial or total fermentation by colon bacteria (Lunn \& Buttriss, 2007). These characteristics generate beneficial health effects such as risk reduction of cardiovascular disease, some cancers, diabetes, obesity and prevention of constipation (Charalampopoulos, Wang, Pandiella, \& Webb, 2002; Topping, 2007).

Inulin is considered a DF, since only one enzyme, the inulinase is able to hydrolyse it. This enzyme is not present in the human gastrointestinal tract, and therefore inulin reaches the colon intact, where is fermented by anaerobic bacteria producing short chain fatty acids (Lunn \& Buttriss, 2007). Chemically it consist on linear D-fructose bonded by $\beta$-(1-2) linkages with or without an end glucose residue, with a degree of polymerization (DP) ranging between 10 and 25 (Meyer, Bayarri, Tarrega, \& Costell, 2011). Inulin in solution tends to form aggregates where water is enclosed and this aggregation is strongly influenced by the DP. Suspensions of high-performance (HP) inulin (DP>23) under certain conditions forms gel structures in solution (Kim, Faqih, \& Wang, 2001). Therefore HP inulin is used as a fat replacement in some kind of food products (Meyer et al., 2011).

It is known that dietary fibre retains more water than wheat flour, which in turn may affect the dough viscosity (Blanco Canalis, Steffolani, León, \& Ribotta, 2016). If dough viscosity increases, a decrease in the dough expansion during baking is expected, which produce a decrease of the maximum diameter and an increment of biscuit hardness.

In a previous study, it was analysed the effects of the incorporation four dietary fibres with different characteristics on dough properties and biscuit quality. The fibres used were inulin, oat fibre and two resistant starches (Blanco Canalis et al., 2016). In a subsequent investigation a particular emphasis was placed on the distribution and mobility of protons by Nuclear Magnetic Resonance (NMR) and the rheological properties of dough (Serial et al., 2016). In these studies inulin showed an improving effect on the biscuit expansion, dimensions and hardness when an all-purpose flour was used. Due to the large differences in quality among flours used for biscuit production it is important to know whether these results are extended to different types of flours, this paper aimed to analyse the effect of 
inulin incorporation at two levels on the quality of dough and biscuits made with three different wheat flours and one triticale flour. Inulin levels were $6 \%(\mathrm{w} / \mathrm{w})$ and $12 \%(\mathrm{w} / \mathrm{w})$. These levels were chosen according to a previous investigation since they allow to fulfil $\sim 10 \%$ and $\sim 20 \%$ of the daily reference value per serving (two biscuits), respectively (FAO/WHO, 1998).

\section{Materials and Methods}

\section{$2.1 \quad$ Samples}

Wheat grains from hard wheat (Baguette 10, BAG), soft wheat (BIOINTA 3007, SWF) and triticale (Tatú, TRI) cultivars were obtained and ground with AQC 109-Laboratoy MillAgromatic AG (Switzerland). A commercial hard wheat flour (HWF) was also tested. Inulin (Orafti ${ }^{\circledR} \mathrm{HP}$ ) was obtained from Orafiti Food Ingredients (Belgium), with a degree of polymerization greater than 23 .

\subsection{Chemical and physic-chemical analysis of flours}

The composition and flour quality was determined through physico-chemical assays. Moisture (AACC, Method 44-01), ash (AACC, Method 08-01) and solvent retention capacity (SRC) (AACC, Method 56-11) were determined. Damaged starch was determined through enzymatic hydrolysis with fungal $\alpha$-amylase and subsequent titration of reducing sugars (AACC, Method 76-11A). Protein content was determined by micro Kjeldahl method and the nitrogen conversion factor used was 5.7 (AACC, Method 46-13) (AACC, 2000). The analysis were conducted in duplicate.

\subsection{Biscuits preparation}

To determine biscuit quality, biscuits were formulated with the four analysed flours. Biscuits were prepared according to Barrera, Perez, Ribotta, and Leon (2007). The ingredients used per biscuit batch were flour (45 g), caster sugar (27 g), vegetable shortening (20.2 g), powdered skim milk (2.25 g), $\mathrm{NaHCO}_{3}(0.50 \mathrm{~g}), \mathrm{NaCl}(0.42$ $\mathrm{g})$, and $6 \mathrm{~mL}$ of water. Inulin was incorporated at two levels, $6 \mathrm{~g}$ and $12 \mathrm{~g}$ with 39 and $33 \mathrm{~g}$ (instead of $45 \mathrm{~g}$ ) of flour respectively being used, corresponding to $\sim 6 \%$ and $\sim 12 \% \mathrm{w} / \mathrm{w}$ of the total of dry ingredients, respectively.

The dough was manually sheeted to a $0.7 \mathrm{~cm}$ thickness and cut in circles of $4.5 \mathrm{~cm}$ of diameter and placed on an aluminium sheet. Six pieces were obtained from each batch.

The biscuits were baked for $11 \mathrm{~min}$ at $180^{\circ} \mathrm{C}$ in a forced convection oven (Pauna, Argentina) equipped with a temperature controller. The six biscuit pieces were placed in the centre of the oven and baked. After baking, the biscuits were cooled down to room temperature prior to analysis $\left(\sim 20^{\circ} \mathrm{C}\right)$. The baking tests and associated measurements were replicated three times for each sample.

\subsection{Dough and biscuit evaluation}

Dynamic diameter measurements. In order to monitor changes in biscuit dimensions during baking, videos were taken during baking using a digital camera (Sony DSC-W320, Japan) (Blanco Canalis et al., 2016). Four biscuits were monitiored in each trial. A calibrated metal bar was used in each test as a dimension reference. Images were stored in AVI format. The AVI files obtained were analysed by ImageJ software (National Institutes Health, USA) to obtain biscuit diameter and spread rate at $30 \mathrm{~s}$ intervals after calibration of the image using the metal reference. Three parameters were determined from these profiles: maximum diameter of biscuit pieces reached during baking (MD), biscuit set time (ST) and spread rate (SR). Biscuit set time was defined as the time at which the biscuit reaches its maximum spread during baking and the spread rate is the linear slope of diameter increase during the first part of the baking process. Four biscuits at each cooking batch and three batches were measured to ensure reliable results. The values of $\mathrm{MD}, \mathrm{ST}$ and spread rate are the average of the biscuits measured of each sample.

Biscuit Factor. Six biscuits were produced in each batch and 4 biscuits (the most homogeneous 
ones) were selected to determine the biscuit factor. To quantify biscuit quality, the term biscuit factor (BF) was introduced as the ratio between the width and thickness of four biscuits taken at random (Leon et al., 1996) . Biscuits were tested in triplicate to ensure reliable results.

Biscuit texture. The breaking strength was measured with the triple beam snap technique using Universal Testing machine (INSTRON 3342, USA) with a load cell of $500 \mathrm{~N}$ (Blanco Canalis et al., 2016). The base gap of the two support beams was adjusted to $36 \mathrm{~mm}$. Each biscuit was centred on the base and the travel distance of the blade was $35 \mathrm{~mm}$, and test speed was set at $0.5 \mathrm{~mm} / \mathrm{s}$. The average value of four replicates from three independent biscuit production batches was performed. Hardness $(\mathrm{H})$ required to produce the total break of the biscuit structure was also retained.

Biscuit surface colour in terms of brightness $\left(\mathrm{L}^{*}\right)$, redness $\left(\mathrm{a}^{*}\right)$, and yellowness $\left(\mathrm{b}^{*}\right)$ was measured using a spectrophotometer (Minolta CM-500 d series, Japan) for all the batch produced.

The whiteness values of biscuits were calculated for 4 biscuits per batch as described by Hsu et al (Hsu, Chen, Weng, \& Tseng, 2003) (Equation 1)

$$
100-\sqrt{\left(100-L^{*}\right)^{2}+a^{* 2}+b^{* 2}}
$$

Where:

$\mathrm{L}^{*}=$ brightness

$\mathrm{a}^{*}=$ redness colour

$\mathrm{b}^{*}=$ yellowness colour

\subsection{Statistics analysis}

The data obtained were statistically tested by variance analysis, while the means were compared using Fisher's LSD test at a significance level of 0.05. Correlation between variables was determined using Pearson's coefficient. These tests were carried out using INFOSTAT statistical software (Di Rienzo et al., 2011).

\section{Results and Discussion}

Protein content is a parameter that is important to determine dough behaviour, since it positively correlates with the water absorption and the gluten development; both unwanted properties in this type of products, as they negatively affect the biscuit quality (Navickis, Anderson, Bagley, \& Jasberg, 1982). Results showed significant differences in protein content between samples with values ranging from $8.05 \%$ to $11.59 \%$ (Table 1).

The flour moisture has an important role in the biscuit manufacture, even more than the total dough moisture, in determining the surface cracking. Higher flour moisture results in an increase on water diffusion rate through the biscuit surface, during baking. Consequently higher moisture flours would produce biscuits with a reduced degree of cracking, which is an undesirable effect (Doescher \& Hoseney, 1985). Results did not show differences among the analysed samples (Table 1).

At room temperature damaged starch (DS) granules absorbs between $200 \%$ and $430 \%$ of its own weight in water, while native starch granules absorbs between $39 \%$ and $87 \%$. The increase of the water absorption capacity of the flour usually results in doughs that are difficult to manipulate, have lower spreading action and longer baking times (Berton, Scher, Villieras, \& Hardy, 2002; Pareyt \& Delcour, 2008). Damaged starch values showed significant differences among fours (Table 1), ranging between $10.39 \%$ (HWF) and $7.89 \%$ (soft wheat flour, SWF). These results were expected since harder grains require greater compression force to break them, further damaging the starch granules (Hoseney, 1994).

Color is an important factor in the determination of biscuit quality, since it has influence in the overall consumer acceptability. Ash content is one of the flour components that has great influence on biscuit color (Jeltema, Zabik, \& Thiel, 1983; Ribotta, Leon, Aguirre, \& Beltramo, 2002). Ash content ranged from $0.77 \%$ for $\mathrm{HWF}$ and $0.60 \%$ for Baguette (Table 1), indicating a greater bran contamination in the hard wheat flour.

The solvent retention capacity (SRC) values among flours showed significant differences $(\mathrm{p}<0.05)$ (Table 2). The higher value of SRC-L was found for HWF, while the lowest value was observed in triticale. SRC-L did not correlate with protein content, in agreement to Guttieri, Bowen, Gannon, O'Brien, and Souza (2001) and 
Inulin-enriched biscuit quality $\mid 17$

Table 1: Chemical parameters of the flours. SWF: soft wheat flour. HWF: hard wheat flour. DS: damage starch

\begin{tabular}{lllll}
\hline Sample & \% Moisture & \% Ashes & \%DS & \% Proteins \\
\hline Triticale & $14.32 \pm 0.21^{a}$ & $0.66 \pm 0.02^{b}$ & $8.90 \pm 0.29^{b}$ & $9.83 \pm 0.04^{b}$ \\
SWF & $14.02 \pm 0.19^{a}$ & $0.62 \pm 0.00^{a b}$ & $7.87 \pm 0.29^{a}$ & $10.52 \pm 0.20^{b}$ \\
Baguette & $14.18 \pm 0.02^{a}$ & $0.60 \pm 0.02^{a}$ & $9.72 \pm 0.29^{c}$ & $8.05 \pm 0.22^{a}$ \\
HWF & $14.28 \pm 0.00^{a}$ & $0.77 \pm 0.02^{b}$ & $10.39 \pm 0.27^{d}$ & $11.59 \pm 0.02^{b}$ \\
\hline
\end{tabular}

Values with common letter are not significantly different $\mathrm{p}>0.05$

Roccia et al. (2006), working with triticale and soft wheat flour.

Soft wheat showed the lowest SRC-C and DS values, while hard flour showed the highest values. Previous studies (Colombo, Perez, Ribotta, \& Leon, 2008; Moiraghi et al., 2005; Peña \& Amaya, 1980) showed that triticale and bread wheat flours had significant and positive correlations between the SRC-C values and damaged starch content. In agreement with Guttieri et al. (2001), the SRC-C values and DS allowed to characterized triticale as harder than soft wheat. Hard wheat flour showed the highest values of the four solvent of SRC, which is in agreement with the ash, moisture, damaged starch and total protein contents (Table 1, 2).

Flour is the principal raw material of biscuit, therefore its physicochemical characteristics define the ability to produce good quality biscuits. As was stated before, for biscuit manufacturing gluten development is undesirable, as it results in an elastic dough that shrinks at the final stage of the baking process. Water absorption is a critical parameter and is influenced by many flour components. A flour with great water absorption not only affects the dough manipulation, but also requires more baking time to eliminate the excess of water.

During the first part of the baking process, fat melts and sucrose dissolved progressively, increasing the system mobility. These changes promote a linear increase in the biscuit diameter until it reaches a maximum and remains fixed (Abboud et al., 1985). Previous works have shown the longer the biscuit spreading time the better the final product quality (Blanco Canalis et al., 2016; Miller, Hoseney, \& Morris, 1997).

Figure 1 shows the changes in the dough piece diameter $\left(\mathrm{cm}_{t} / \mathrm{cm}_{0}\right)$ during baking (only control and $12 \%$ inulin samples were included in the figure to make it clearer, since $6 \%$ curves resulted intermediate between control and 12\%). The baking profile showed a fast increase in diameter during the first minutes until a maximum. Then it decreased showing a slight shrinking at the end of the baking time.

Biscuit dough made from Baguette flour spread the most, reaching the largest maximum diameter in the oven, while HWF showed the least spread.

SWF and HWF doughs showed a significant increase of the maximum diameter during baking when inulin was incorporated, reaching the highest value at $12 \%$ level which represented about $20 \%$ increase over SWF C (Table 3).

The slope of the linear part of the curve (spread rate, SR) showed significant differences among the flour samples and ranged between $0.23 \mathrm{~min}^{-1}$ (HWF) and 0.52 min-1 (SWF) for doughs without inulin addition. Higher values of SR are associated with longer spreading process and better biscuit quality (Stauffer, 1994). The spread rate is related to the dough viscosity and, as was expected it is in concordance with SRC water values: the lowest the SRC-W, the faster dough expansion (Table 2 and 3). SWF doughs presented the highest SR values, while HWF showed the lowest. In general a progressive increase of SR was noticed with inulin incorporation (only triticale samples showed no differences). Although SWF $12 \%$ showed the highest value, HWF presented the greatest increment, since $12 \%$ inulin incorporation increased SR about $43 \%$ over HWF control dough.

Previous studies have demonstrated that the longer the dough spread in the oven and the 
Table 2: Solvent retention capacity of the flours. SWF: soft wheat flour. HWF: hard wheat flour. SRC-C: carbonate solvent retention capacity. SRC-W: water solvent retention capacity. SRC-S: sucrose solvent retention capacity. SRC-L: lactic acid solvent retention capacity

\begin{tabular}{lllll}
\hline Sample & SRC-C & SRC-W & SRC-S & SRC-L \\
\hline Triticale & $80.99 \pm 0.20^{c}$ & $64.94 \pm 0.08^{a}$ & $98.45 \pm 0.09^{c}$ & $68.75 \pm 0.07^{a}$ \\
SWF & $72.86 \pm 0.09^{a}$ & $62.91 \pm 4.54^{a}$ & $85.41 \pm 0.22^{a}$ & $97.64 \pm 2.64^{c}$ \\
Baguette & $77.47 \pm 0.29^{b}$ & $63.07 \pm 0.00^{a}$ & $91.47 \pm 0.41^{b}$ & $89.54 \pm 1.30^{b}$ \\
HWF & $89.00 \pm 0.50^{d}$ & $71.90 \pm 0.70^{b}$ & $107.90 \pm 2.70^{d}$ & $108.60 \pm 1.80^{d}$ \\
\hline
\end{tabular}

Values with common letter are not significantly different $\mathrm{p}>0.05$

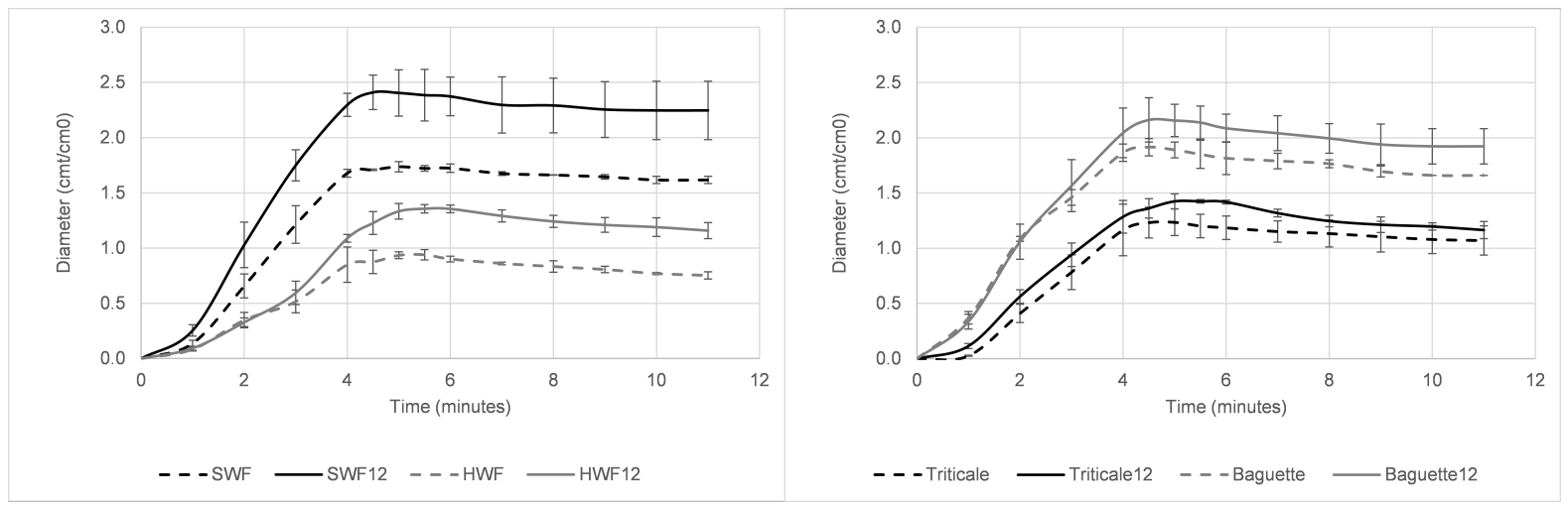

Figure 1: Changes in dough diameter formulated with different flours during baking. SWF: soft wheat flour. HWF: hard wheat flour. Triticale: triticale flour. Baguette: baguette flour, 12 refers to the level of inulin

higher set time, the better the biscuit quality (Blanco Canalis et al., 2016). No statistical differences were found between the biscuit set time (ST) values among the control samples (without inulin) and similar behaviour was found as consequence of inulin incorporation. Only triticale $6 \%$ showed an increment of ST compared to triticale C (Table 3, Fig. 1).

Inulin is a soluble fibre and its solubility increases with temperature. It seems that during baking inulin progressively dissolves resulting in a rise of the spread rate and maximum diameter, which improved biscuit quality (Blanco Canalis et al., 2016). This effect is similar to that achieved by an increase of fat level, since fat melts during baking and contributes to the system mobility (Pareyt et al., 2009).

It is generally accepted that a good biscuit formulation produces tender final products with large diameter and with uniform surface-cracking pattern. Biscuits produced with Baguette flour had the highest BF values and no significant differences were found among SWF, HWF and triticale flour samples without fibre (Table 4). Biscuit factor increased as consequence of IN incorporation at 6 and $12 \%$ for all tested flours. The highest $\mathrm{BF}$ values were produced by Baguette flour and IN at $6 \%$ and $12 \%$. However, the greatest increments of BF related to the control without IN were showed by soft wheat biscuits, since it increased $\sim 48 \%$ and $\sim 65 \%$ with 6 and $12 \%$ inulin incorporation, respectively (Table 4, Fig. 2 ). These results are consistent with the dough spread ratio and maximum diameter reached in the oven, considering that in the second part of the baking process the pieces undergo a shrinkage.

The surface colour of biscuits is, together with 
Inulin-enriched biscuit quality $\mid 19$

Table 3: Effects of inulin addition on dough quality parameters. SWF: soft wheat flour doughs. HWF: hard wheat flour doughs. Triticale: triticale flour doughs. Baguette: baguette flour doughs. C: control dough sample. $6 \%$ and $12 \%$ refer to the level of inulin.MD: maximum diameter during baking. ST: set time. SR: spread rate

\begin{tabular}{llll}
\hline Sample & MD $[\mathrm{cm}]$ & ST [min] & SR \\
\hline Triticale C & $5.62 \pm 0.37^{a B}$ & $4.42 \pm 0.35^{a A}$ & $0.38 \pm 0.03^{a B}$ \\
Triticale 6\% & $5.89 \pm 0.20^{a}$ & $5.67 \pm 0.00^{b}$ & $0.38 \pm 0.04^{a}$ \\
Triticale 12\% & $5.56 \pm 0.06^{a}$ & $5.09 \pm 0.12^{a b}$ & $0.38 \pm 0.03^{a}$ \\
SWF C & $5.96 \pm 0.06^{a B C}$ & $5.00 \pm 0.51^{a A}$ & $0.52 \pm 0.00^{a C}$ \\
SWF 6\% & $6.94 \pm 0.06^{b}$ & $5.34 \pm 0.24^{a}$ & $0.59 \pm 0.03^{b}$ \\
SWF 12\% & $7.09 \pm 0.33^{b}$ & $4.84 \pm 0.47^{a}$ & $0.69 \pm 0.01^{c}$ \\
Baguette C & $6.34 \pm 0.00^{a C}$ & $4.50 \pm 0.00^{a A}$ & $0.43 \pm 0.01^{a B}$ \\
Baguette 6\% & $6.53 \pm 0.11^{a}$ & $5.42 \pm 0.50^{a}$ & $0.47 \pm 0.00^{a}$ \\
Baguette 12\% & $6.57 \pm 0.26^{a}$ & $4.75 \pm 0.35^{a}$ & $0.52 \pm 0.02^{b}$ \\
HWF C & $4.85 \pm 0.13^{a A}$ & $4.84 \pm 0.44^{a A}$ & $0.23 \pm 0.02^{a A}$ \\
HWF 6\% & $5.84 \pm 0.55^{b}$ & $4.58 \pm 0.35^{a}$ & $0.28 \pm 0.01^{a b}$ \\
HWF 12\% & $5.58 \pm 0.24^{b}$ & $5.42 \pm 0.12^{a}$ & $0.33 \pm 0.01^{b}$ \\
\hline
\end{tabular}

Values with common letter are not significantly different $\mathrm{p}>0.05$. Capital letters concern to differences between control samples.

Table 4: Effect of inulin addition on biscuit quality parameters. SWF: soft wheat flour biscuits. HWF: hard wheat flour biscuits. Triticale: triticale flour biscuits. Baguette: baguette flour biscuits. C: control biscuits. $6 \%$ and $12 \%$ refer to the level of inulin. BF: biscuit factor. WV: whiteness value. H: hardness

\begin{tabular}{llll}
\hline Sample & BF $[\mathrm{cm} / \mathrm{cm}]$ & WV & $\mathrm{H}[\mathrm{N}]$ \\
\hline Triticale C & $5.49 \pm 0.07^{a A}$ & $53.01 \pm 2.58^{a A B}$ & $88.0 \pm 2.1^{b C}$ \\
Triticale 6\% & $7.10 \pm 0.18^{b}$ & $50.59 \pm 2.83^{a}$ & $68.4 \pm 6.1^{b}$ \\
Triticale 12\% & $6.63 \pm 0.25^{b}$ & $48.28 \pm 0.74^{a}$ & $81.9 \pm 8.1^{b}$ \\
SWF C & $5.42 \pm 0.50^{a A}$ & $45.42 \pm 2.17^{a A}$ & $70.3 \pm 5.5^{b B}$ \\
SWF 6\% & $8.01 \pm 0.77^{b}$ & $45.13 \pm 1.89^{a}$ & $48.5 \pm 4.8^{a}$ \\
SWF 12\% & $8.92 \pm 0.89^{b}$ & $44.30 \pm 0.15^{a}$ & $41.7 \pm 4.1^{a}$ \\
Baguette C & $7.30 \pm 0.34^{a B}$ & $52.82 \pm 5.18^{a A B}$ & $38.9 \pm 3.3^{a A}$ \\
Baguette 6\% & $9.61 \pm 0.42^{b}$ & $49.30 \pm 1.91^{a}$ & $37.4 \pm 2.7^{a}$ \\
Baguette 12\% & $9.67 \pm 0.04^{b}$ & $50.17 \pm 1.14^{a}$ & $46.1 \pm 4.2^{b}$ \\
HWF C & $4.69 \pm 0.16^{a A}$ & $57.60 \pm 4.18^{a B}$ & $72.8 \pm 5.9^{b B}$ \\
HWF 6\% & $5.71 \pm 0.15^{b}$ & $53.62 \pm 3.67^{a}$ & $69.3 \pm 5.9^{a b}$ \\
HWF 12\% & $6.05 \pm 0.19^{b}$ & $51.97 \pm 1.21^{a}$ & $62.7 \pm 6.2^{a}$ \\
\hline
\end{tabular}

Values with common letter are not significantly different $\mathrm{p}>0.05$. Capital letters concern to differences between control samples. 


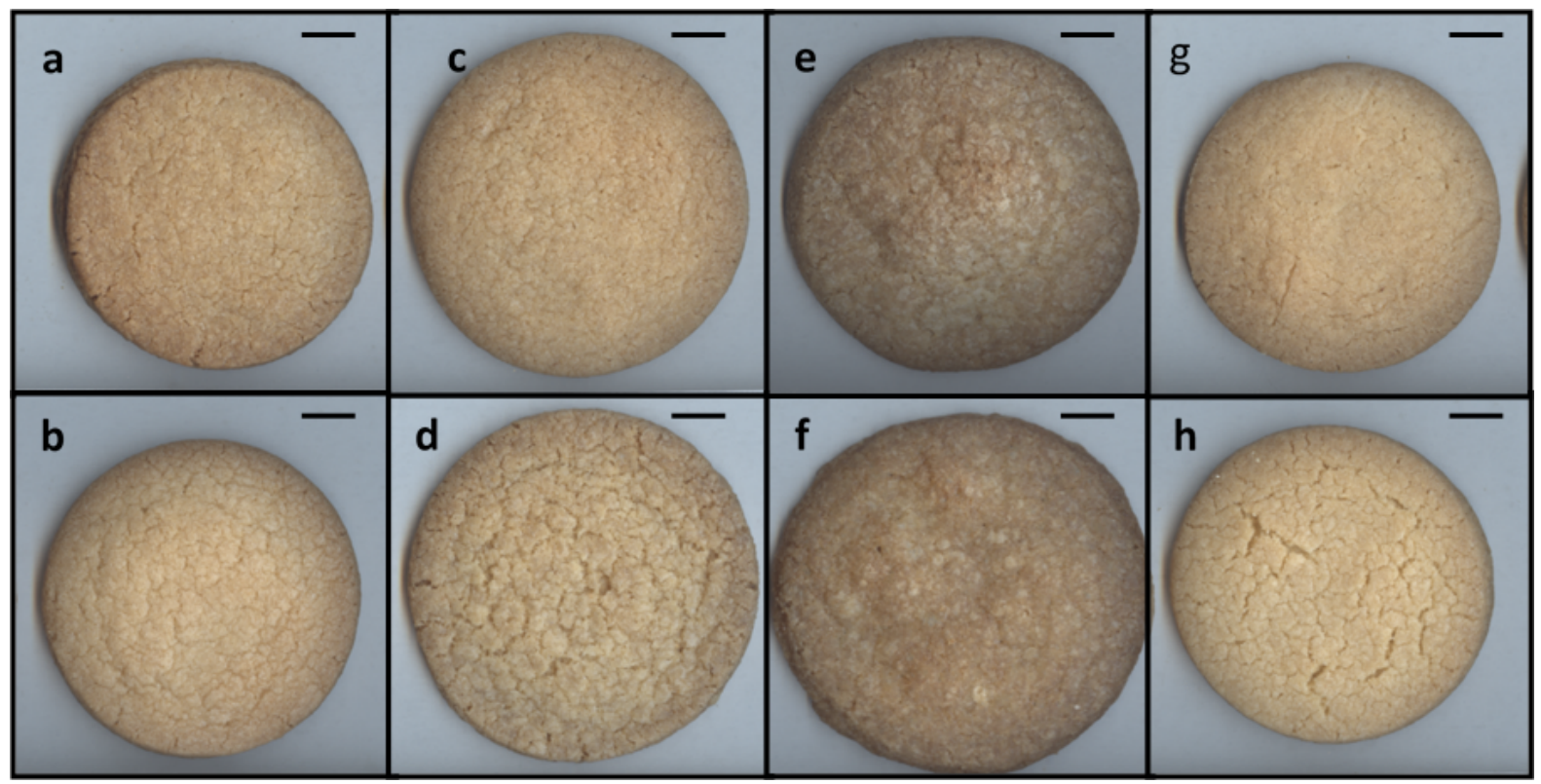

Figure 2: Effects of fiber incorporation on the superficial aspect of the biscuits. a: triticale control. b: triticale $12 \%$ inulin incorporation. c: baguette control. d: baguette $12 \%$ inulin incorporation. e: soft wheat flour control. f: soft wheat flour $12 \%$ inulin incorporation. g: hard wheat flour control. h: hard wheat flour $12 \%$ inulin incorporation. Scale: $1 \mathrm{~cm}$

texture and taste, a very important element for the initial acceptability by consumers. The whiteness value mathematically combines lightness, the red-green and yellow-blue into a single term and has been used to compare colour in this study. The higher the whiteness value the whiter the sample.

Whiteness value ranged between 44.3 (SWF $12 \%$ ) and 57.6 (HWF C), indicating that the caramelization process and Maillard reaction (which produce surface browning) during baking was less intense in biscuits made from HWF, resulting in paler products (Table 4, Fig. 2). Whiteness value showed no significant changes as consequence of fibre addition when compared samples to each control.

The biscuit average breaking force (hardness) showed differences between the samples. Triticale biscuits were the hardest while Baguette biscuits were the tenderest. Biscuit hardness values are usually related to piece dimensions, the thinner the biscuit the lower the force require to produce the total structure break (Table 4 ). It was expected that an increase in the ratio between the width and thickness together with the structure changes caused by the fibre addition contributed to a tenderer product. However, the results showed not clear trends in this parameter. Inulin incorporation to soft wheat flour and commercial hard wheat flour decreased hardness. Similar results were found in a previous study (Blanco Canalis et al., 2016). When triticale flour was used, $6 \%$ of inulin incorporation reduced this parameter but $12 \%$ of inulin had a similar value to the triticale control biscuit. Regarding Baguette flour, an increase of breaking force was found at $12 \%$ of inulin, indicating that at a similar biscuit factor the increment of inulin increased the hardness of the biscuits (Table 4). It is known that HP inulin is able to form gels in solution (Glibowski \& Wasko, 2008). It is suggested that the IN network increased the biscuit hardness. Therefore, the net result of the incorporation of inulin may be a balance of the change in the BF and the IN ability to form network structures (Table 4). 
The final biscuit diameter and quality is controlled by the rate of expansion in the oven, which depends on the dough viscosity and the set time when biscuit stops spreading. The spread of the biscuit is caused by two factors, i.e. expansion of the dough by leavening and gravitational flow (Hoseney \& Rogers, 1994). As was expected, biscuit height increased linearly until reaching a maximum and then collapsed (results not shown), which is related to doughs with poor or no development of a three dimension gluten network.

In previous studies, it was suggested that the enhancing effect of inulin was related to the extra lubrication factor at lower baking times which in turn produced a highest viscous to elastic behaviour during heating. Besides, they suggested an extra increment of the volume of the sugarwater phase as a consequence of inulin incorporation in the dough aqueous phase since its high content of water soluble fraction $(60.10 \mathrm{~g}$ soluble solids / $100 \mathrm{~g}$ fibre) (Blanco Canalis et al., 2016; Serial et al., 2016). These results were in agreement with those reported by Peressini and Sensidoni (Peressini \& Sensidoni, 2009), who suggested that the particular conformation of inulin HP molecules allows formation of bond areas where a large amount of water is enclosed.

\section{Conclusions}

The present work revealed that inulin significantly changed the dough behaviour during baking and improved their spread ratio and biscuit final diameter regardless of the type of flour used. Consequently the ratio between the width and thickness of biscuits increased.

Inulin incorporation did not demonstrate a clear trend on biscuit hardness among the tested flours. It was suggested that the hardness of the biscuits was affected by the final dimensions of the biscuit and the ability of inulin to form network structures.

This demonstrates that the inulin effect goes beyond the flour quality and depends on the substitution level. The results may be useful to help develop fiber-rich biscuits from different flours and their mixtures without negative effects on their quality.

\section{Acknowledgements}

The authors would like to acknowledge Consejo Nacional de Ciencia y Técnica (CONICET), Secretaría de Ciencia y Tecnología (SECYT) of the Universidad Nacional de Córdoba (UNC) and the Fondo para la Investigación, Ciencia y Tecnología and Ministerio de Ciencia y Tecnología (FONCyT) for financial support.

\section{References}

AACC. (2000). Approved Methods of the American Association of Cereal Chemists, 10th Ed. Method 18-21. In American Association of Cereal Chemists, St. Paul, MN. USA.

Abboud, A. M., Rubenthaler, G. L., \& Hoseney, R. C. (1985). Effect of fat and sugar in sugar-snap cookies and evaluation of tests to measure cookie flour quality. $\mathrm{Ce}$ real Chemistry, 62 (2), 124-129.

Aguirre, A., Badiali, O., Cantarero, M., Leon, A., Ribotta, P., \& Rubiolo, O. (2002). Relationship of test weight and kernel properties to milling and baking quality in Argentine triticales. Cereal Research Communications, 30(1-2), 203-208.

Barrera, G. N., Perez, G. T., Ribotta, P. D., \& Leon, A. E. (2007). Influence of damaged starch on cookie and bread-making quality. European Food Research and Technology, 225(1), 1-7. doi:10.1007/s00217-0060374-1

Berton, B., Scher, J., Villieras, F., \& Hardy, J. (2002). Measurement of hydration capacity of wheat flour: influence of composition and physical characteristics. Powder Technology, 128 (2-3), 326-331. doi:10.1016/S00325910(02)00168-7

Blanco Canalis, M. S., Steffolani, M. E., León, A. E., \& Ribotta, P. D. (2016). Effect of different fibers on dough properties and biscuit quality. Journal of the Science of Food and Agriculture. doi:10.1002/jsfa.7909

Bushuk, W. \& Larter, E. N. (1980). Triticale: production, chemistry, and technology., $115-157$. 
Charalampopoulos, D., Wang, R., Pandiella, S. S., \& Webb, C. (2002). Application of cereals and cereal components in functional foods: a review. International Journal of Food Microbiology, 79(1-2, SI), 131-141. International Symposium on Frontiers in Microbial Preservation and Fermentation, WAGENINGEN, NETHERLANDS, JAN 09-11, 2002. doi:10.1016/S0168-1605(02) 00187-3

CIMMYT. (1985). Research report. Mexico City. Colombo, A., Perez, G. T., Ribotta, P. D., \& Leon, A. E. (2008). A comparative study of physicochemical tests for quality prediction of Argentine wheat flours used as corrector flours and for cookie production. Journal of Cereal Science, 48(3), 775-780. doi:10. 1016/j.jcs.2008.05.003

Di Rienzo, J. A., Casanoves, F., Balzarini, M. G., Gonzalez, L., Tablada, M., \& Robledo, C. W. (2011). Infostat. Universidad $\mathrm{Na}$ cional de Córdoba. Retrieved from www. infostat.com.ar

Doescher, L. C. \& Hoseney, R. C. (1985). Effect of sugar type and flour moisture on surface cracking of sugar-snap cookies. Cereal Chemistry, 62(4), 263-266.

FAO/WHO. (1998). Food Standards Programme. Guidelines for Use of Nutrition Claims. Joint Codex Alimentarius. Rome.

Glibowski, P. \& Wasko, A. (2008). Effect of thermochemical treatment on the structure of inulin and its gelling properties. International Journal of Food Science and Technology, 43(11), 2075-2082. doi:10.1111/j. 1365-2621.2008.01825.x

Guttieri, M. J., Bowen, D., Gannon, D., O'Brien, K., \& Souza, E. (2001). Solvent retention capacities of irrigated soft white spring wheat flours. Crop Science, 41(4), 10541061.

Hoseney, R. C. (1994). Principles of cereal science and technology. 2nd edn., st paul, mn, usa: american association of cereal chemists. Inc.

Hoseney, R. C. \& Rogers, D. E. (1994). Mechanism of sugar functionality in cookies. The science of cookie and cracker production, 1, 203-225.
Hsu, C. L., Chen, W. L., Weng, Y. M., \& Tseng, C. Y. (2003). Chemical composition, physical properties, and antioxidant activities of yam flours as affected by different drying methods. Food Chemistry, 83(1), 8592. doi:10.1016/S0308-8146(03)00053-0

Jeltema, M. A., Zabik, M. E., \& Thiel, L. J. (1983). Prediction of cookie quality from dietary fiber components. Cereal Chemistry, 60(3), 227-30.

Kim, Y., Faqih, M. N., \& Wang, S. S. (2001). Factors affecting gel formation of inulin. Carbohydrate Polymers, 46(2), 135-145. doi:10.1016/S0144-8617(00)00296-4

Leon, A. E., Rubiolo, A., \& Anon, M. C. (1996). Use of triticale flours in cookies: Quality factors. Cereal Chemistry, 73(6), 779-784.

Lunn, J. \& Buttriss, J. L. (2007). Carbohydrates and dietary fibre. Nutrition Bulletin, 32(1), 21-64. doi:10 . 1111 / j. 1467 - 3010 . 2007. 00616.x

Meyer, D., Bayarri, S., Tarrega, A., \& Costell, E. (2011). Inulin as texture modifier in dairy products. Food Hydrocolloids, 25(8), 18811890. doi:10.1016/j.foodhyd.2011.04.012

Miller, R. A., Hoseney, R. C., \& Morris, C. E. (1997). Effect of formula water content on the spread of sugar-snap cookies. Cereal Chemistry, 74(5), 669-671. doi:10.1094/ CCHEM.1997.74.5.669

Moiraghi, M., Ribotta, P. D., Aguirre, A., Pérez, G. T., \& León, A. E. (2005). Análisis de la aptitud de trigos pan para la elaboración de galletitas y bizcochuelos. Agriscientia, 22(2), 47-54.

Morris, C. F. \& Rose, S. P. (1996). Wheat. In Cereal grain quality (pp. 3-54). Springer.

Navickis, L. L., Anderson, R. A., Bagley, E. B., \& Jasberg, B. K. (1982). Viscoelastic properties of wheat-flour doughs - variation of dynamic moduli with water and proteincontent. Journal of Texture Studies, 13(2), 249-264. doi:10.1111/j.1745-4603. 1982 . tb01399.x

Pareyt, B. \& Delcour, J. A. (2008). The role of wheat flour constituents, sugar, and fat in low moisture cereal based products: A review on sugar-snap cookies. Critical Reviews in Food Science and Nutrition, 48(9), 824-839. doi:10.1080/10408390701719223 
Pareyt, B., Talhaoui, F., Kerckhofs, G., Brijs, K., Goesaert, H., Wevers, M., \& Delcour, J. A. (2009). The role of sugar and fat in sugarsnap cookies: Structural and textural properties. Journal of Food Engineering, 90(3), 400-408. doi:10.1111/j.1471-0307.2008.07. 010

Peña, R. \& Amaya, A. (1980). Triticale: un nuevo cereal en desarrollo. Panagfa, 8(76), 48-50.

Peressini, D. \& Sensidoni, A. (2009). Effect of soluble dietary fibre addition on rheological and breadmaking properties of wheat doughs. Journal of Cereal Science, 49(2), 190-201. doi:10.1016/j.jcs.2008.09.007

Ribotta, P., Leon, A., Aguirre, A., \& Beltramo, D. (2002). Instrumental measurement of triticale cookie color. effect of ash content. Informacion Tecnologica, 13(1), 171-174.

Roccia, P., Moiraghi, M., Ribotta, P. D., Perez, G. T., Rubiolo, O. J., \& Leon, A. E. (2006). Use of solvent retention capacity profile to predict the quality of triticale flours. Cereal Chemistry, 83(3), 243-249. doi:10.1094/ CC-83-0243

Rubiolo, O. J., Ferretti, S., Ribotta, P. D., Aguirre, A. V., \& León, A. E. (1998). Incidencia del contenido proteico de las harinas de triticale sobre su aptitud para elaborar galletitas. Información Tecnológica, 9, 8791.

Samela, G. (2011). El consumo de galletitas está entre los más altos del mundo. Retrieved from http://www.clarin.com/empresas_y_ negocios/consumo-galletitas-altos-mundo_ 0_H1nlt25hwmg.html

Serial, M. R., Blanco Canalis, M. S., Carpinella, M., Valentinuzzi, M. C., Leon, A. E., Ribotta, P. D., \& Acosta, R. H. (2016). Influence of the incorporation of fibers in biscuit dough on proton mobility characterized by time domain NMR. Food Chemistry, 192, 950-957. doi:10.1016/j.foodchem.2015.07. 101

Slade, L. \& Levine, H. (1994). Structure-function relationships of cookie and cracker ingredients. The science of cookie and cracker production, 23-141.

Stauffer, C. E. (1994). Redox systems in cookie and cracker dough. The Science of Cookie and Cracker Production, Ed. Faridi $H$
Chapman and Hall, New York, USA, 227251.

Topping, D. (2007). Cereal complex carbohydrates and their contribution to human health. Journal of Cereal Science, 46(3), 220-229. doi:10.1016/j.jcs.2007.06.004

Tsen, C. C. \& Tsen, C. C. (1974). Bakery products from triticale flours. in triticale: first man-made cereal (T. C., Ed.). St. Paul, MN, USA: American Association of Cereal Chemistry.

Varughese, G. (1991). Recognizing triticale's proper place among the world's cereals. In 2. proceedings of the international triticale symposium, passo fundo (brazil), 1-5 oct 1990. CIMMYT. 